\title{
KARAKTERISTIK KELUARGA DAN POLA KONSUMSI PANGAN BALITA DI WILAYAH LOCUS STUNTING KECAMATAN BALANIPA KABUPATEN POLEWALI MANDAR
}

\author{
Indrastuti $^{1 *}$, Arlinda Puspita Sari², Nuraliah ${ }^{3}$ \\ 1, Fakultas Pertanian dan Kehutanan, Universitas Sulawesi Barat \\ 2, Fakultas Keguruan dan Ilmu pendidikan, Universitas Sulawesi Barat \\ 3, Fakultas Kesehatan, Universitas Sulawesi Barat \\ *Email: indrastuti@unsulbar.ac.id
}

\begin{abstract}
Abstrak
Pola konsumsi pangan dan kebiasaan makan yang tidak memenuhi standar gizi menjadi salah satu faktor buruknya status gizi pada balita. Usia di bawah lima tahun merupakan usia emas dalam pembentukan sumber daya manusia baik dari segi pertumbuhan fisik maupun kecerdasan dimana ini dapat didukung oleh status gizi yang baik. Status gizi berperan dalam menentukan sukses tidaknya upaya peningkatan sumber daya manusia. Berkaitan dengan itu, penelitian ini mengambil lokasi penelitian pada salah satu kabupaten yang memiliki prevalensi stunting tertinggi dan menjadi wilayah target percepatan penurunan stunting, yaitu Kabupaten Polewali Mandar, Sulawesi Barat. Penelitian ini bertujuan menggambarkan karakteristik keluarga dan pola konsumsi pangan balita di wilayah locus stunting, Kabupaten Polewali Mandar. Penelitian ini menggunakan desain cross sectional study dengan total subjek 82 balita. Pengambilan data dilakukan dengan metode simple random sampling pada balita yang memenuhi kriteria inklusi. Hasil penelitian menunjukkan terdapat balita yang mengalami status gizi buruk dan kurang. Konsumsi pangan balita seperti makanan pokok, protein hewani, sayuran dan buah, serta jajanan sebagian besar berada pada kategori rendah, sementara konsumsi pangan berupa protein nabati berada pada kategori cukup.
\end{abstract}

Kata kunci : Karakteristik keluarga, Pola konsumsi pangan, Stunting

\begin{abstract}
Family Characteristics And Food Consumption Patterns Of Food In The Locus Stunting Area, Balanipa District, Polewali Mandar District. The pattern of food consumption and eating habits that do not fulfill nutritional standards are the factors causing the poor nutritional status of children under five. Age under five years is a golden age in the development of human resources both in terms of physical growth and intelligence, where they must be supported by good nutrition. Nutritional status plays a role in determining the success or failure of efforts to increase human resources. In this regard, the research took place in one of the districts that still has the highest prevalence of stunting and is the target area for the acceleration of stunting reduction, namely Polewali Mandar Regency, West Sulawesi. This study aims to describe the family characteristics and pattern of children's food consumption in the Polewali Mandar Regency. This study used a cross-sectional study with a total subject of 82 children. Data were collected using a simple random sampling method on children who met the exclusion criteria. The results showed that there were toddlers who had malnutrition and lack of nutrition. Food consumption for children, such as staple foods, animal protein, vegetables and fruit, and snacks, were mostly in the low category while consumption of food such as vegetables was in the sufficient category.
\end{abstract}

Keywords: Family characteristic, Pattern of food consumption, Stunting. 


\section{Pendahuluan}

Konsumsi pangan erat kaitannya dengan peningkatan mutu gizi pangan dalam meningkatkan mutu sumber daya manusia, yang sudah dicanangkan dalam kebijakan Inpres No. 20 tahun 1979. Pola Konsumsi merupakan kebiasaan makan yang berbeda antara masyarakat satu dengan yang lain,.faktor-faktor yang mempengaruhi pola konsumsi pangan setiap rumah tangga juga menentukan tingkat ketahanan pangan suatu rumah tangga, diantara faktor-faktor yang mempengaruhi pola konsumsi pangan yaitu lingkungan, kultur masyarakat, pendidikan, dan tingkat ekonomi, serta ketersediaan pangan di masyarakat.

Masyarakat di pedesaan cenderung masih mengandalkan produk pangan lokal yang didominasi dari sumber pangan karbohidrat sedangkan menurut Khomsan (2004), skor pola konsumsi pangan mencerminkan mutu gizi konsumsi pangan dan tingkat keragaman konsumsi pangan serta mencerminkan susunan konsumsi pangan anjuran (Khomsan, 2004). Berdasarkan data ketahanan pangan Provinsi Sulawesi Barat tahun 2015 skor PPH yang diperoleh sebesar 87,0, Hal ini menggambarkan komposisi pangan yang dikonsumsi masyarakat Provinsi Sulawesi Barat tidak seimbang. Terjadinya ketidak seimbangan dalam mengkonsumsi pangan yang beragam ditandai dengan komposisi pangan yang diperoleh tidak sesuai dengan komposisi yang diharapkan. Ketidakseimbangan konsumsi pangan mengakibatkan terjadinya gizi kurang dan stunting pada anak khususnya balita Konsumsi pangan harus memiliki tingkat keragaman dalam konsumsi pangan, yaitu terdiri dari sumber karbohidrat, protein, lemak, vitamin dan mineral serta sumber serat.

Pada saat ini balita (di bawah lima tahun) sebagai generasi penerus bangsa yang diharapkan menjadi sumber daya manusia yang berkualitas di masa depan memerlukan perhatian khusus. Usia di bawah lima tahun merupakan usia emas dalam pembentukan sumber daya manusia baik dari segi pertumbuhan fisik maupun kecerdasan dimana ini dapat didukung oleh status gizi yang baik karena status gizi berperan dalam menentukan sukses tidaknya upaya peningkatan sumber daya manusia.

Stunting (pendek) adalah salah satu bentuk gizi kurang yang ditandai dengan indikator tinggi badan menurut umur. Indikator TB/U memberikan indikasi masalah gizi yang sifatnya kronis sebagai akibat dari keadaan yang berlangsung lama. Pola makan dan kebiasaan makan yang kurang baik merupakan salah satu yang dapat menyebabkan anak menjadi stunting. 
Pada tahun 2017, prevalensi balita sangat pendek dan pendek pada usia 0-59 bulan di Indonesia adalah 9,8\% dan 19,8\%. Kondisi ini meningkat dari tahun sebelumnya yaitu prevalensi balita sangat pendek sebesar 8,5\% dan balita pendek sebesar 19\%. Berdasarkan hasil Survei Status Gizi (PSG) Kementerian Kesehatan pada 2016 menunjukkan bahwa Sulawesi Barat merupakan provinsi dengan tingkat bayi Stunting tertinggi. Dari pemantauan tersebut ditemukan $39,7 \%$ bayi usia 0-59 bulan berada pada status stunting. Jumlah tersebut terdiri atas bayi dengan tinggi badan sangat pendek $14,7 \%$ ditambah $25 \%$ bayi pendek. Kemudian pada tahun 2017 angka stunting di Sulawesi Barat terus meningkat yaitu menjadi $40 \%$. Salah satu kabupaten yang masih memiliki prevalensi stunting tertinggi dan menjadi wilayah target percepatan penurunan stunting adalah Kabupaten Polewali Mandar.

Apabila masalah ini terus berlanjut dan tidak ditangani dengan serius, maka akan berdampak pada kualitas generasi mendatang. Anak balita pada masa golden age period membutuhkan asupan makanan yang sesuai dengan prinsip gizi seimbang untuk menunjang masa pertumbuhan dan perkembangannya. Tentunya anak yang mengalami stunting harus lebih mengutamakan kebutuhan gizinya untuk mengejar pertumbuhannya dibandingkan dengan anak normal lainnya.

Berdasarkan latar belakang dan permasalahan diatas, maka penelitian ini bertujuan menggambarkan karakteristik keluarga dan pola konsumsi pangan balita di wilayah locus stunting, Kabupaten Polewali Mandar.

\section{Metode}

Rancangan penelitian ini adalah deskriptif dengan pendekatan cross-sectional. Sampel penelitian adalah keluarga yang memiliki balita usia<59 bulan dan bersedia mengisi kuesioner. Kriteria eksklusi yaitu anak balita yang sakit atau cacat, responden yang tidak kooperatif dan tidak tahu umur anak balitanya. Pemilihan sampel dilakukan dengan menggunakan teknik simple random sampling. Alat yang digunakan untuk pengumpulan data dalam penelitian ini adalah kuesioner untuk mengetahui karakteristik keluarga dan balita. Status gizi balita diukur dengan indikator berat badan/usia dan diinterpretasikan berdasarkan klasifikasi status gizi WHO. Penelitian dilaksanakan pada bulan Januari sampai pada bulan Agustus 2019. Penelitian ini dilakukan di Kabupaten Polewali Mandar, Kecamatan Balanipa. Jumlah sampel yaitu 82 balita. 


\section{Hasil}

\section{Karakteristik Balita}

Karakteristik dari subjek balita yang terdiri dari usia batita dan prasekolah, untuk batita jumlah subjeknya yaitu laki - laki 33 anak dan perempuan 38 anak dimana dapat dilihat jumlah anak perempuan lebih besar dari jumlah anak laki - laki. Sedangkan subjek prasekolah yaitu terdiri anak laki - laki sebanyak 18 anak dan perempuan 11 anak dimana jumlah anak laki - laki lebih besar dari jumlah anak perempuan.

Tabel 1. Sebaran usia berdasarkan jenis kelamin

\begin{tabular}{lcc}
\hline \multicolumn{1}{c}{ Usia balita } & $\begin{array}{c}\text { Laki-Laki } \\
\text { (n) }\end{array}$ & $\begin{array}{c}\text { Perempuan } \\
\text { (n) }\end{array}$ \\
\hline $\begin{array}{l}\text { 6-36 bulan } \\
\text { (batita) }\end{array}$ & 33 & 38 \\
$\begin{array}{l}\text { 37-59 bulan } \\
\text { (preschool) }\end{array}$ & 18 & 11 \\
\hline
\end{tabular}

Metode antropometri terdiri atas berbagai indeks yang dapat digunakan untuk menilai status gizi, diantaranya berat badan menurut umur $(\mathrm{BB} / \mathrm{U})$, tinggi badan menurut umur $(\mathrm{TB} / \mathrm{U})$ dan berat badan menurut tinggi badan (BB/TB).

\section{Tabel 2. Sebaran status gizi balita}

\begin{tabular}{lcc}
\hline \multicolumn{1}{c}{$\begin{array}{c}\text { Status gizi balita } \\
\text { (BB/Usia) }\end{array}$} & (n) & \% \\
\hline Buruk & 2 & $2 \%$ \\
Kurang & 5 & $6 \%$ \\
Baik & 72 & $89 \%$ \\
Lebih & 3 & $4 \%$ \\
\hline
\end{tabular}

Tabel 2. menunjukkan terdapat $2 \%$ balita yang mengalami gizi buruk dan $6 \%$ gizi kurang. Sebagian besar balita berstatus gizi baik (89\%).

\section{Karakteristik Keluarga}

Pekerjaan ibu sebagian besar adalah ibu rumah tangga dengan tingkat pendidikan yaitu SD: 29\%, SMP: 22\%, SMA: 39\%, dan S1 hanya $2 \%$.

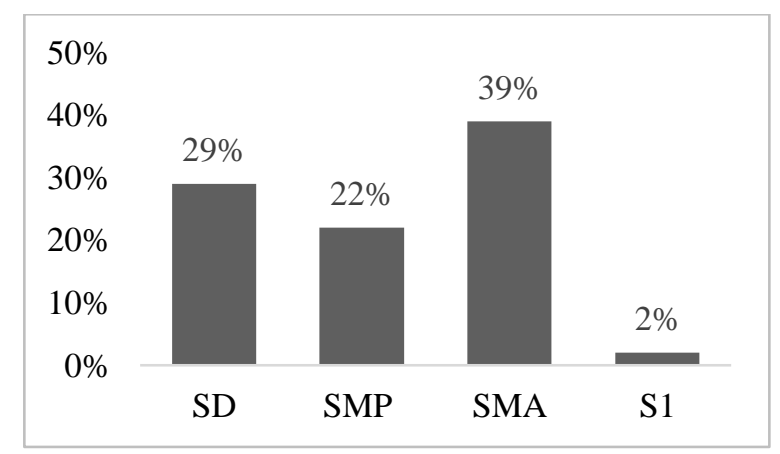

Gambar 1. Persentase pendidikan terakhir Ibu

Tingkat pendapatan kepala keluarga hampir seluruhnya berpendapatan kurang dari Rp. 1.000 .000 (99\%).

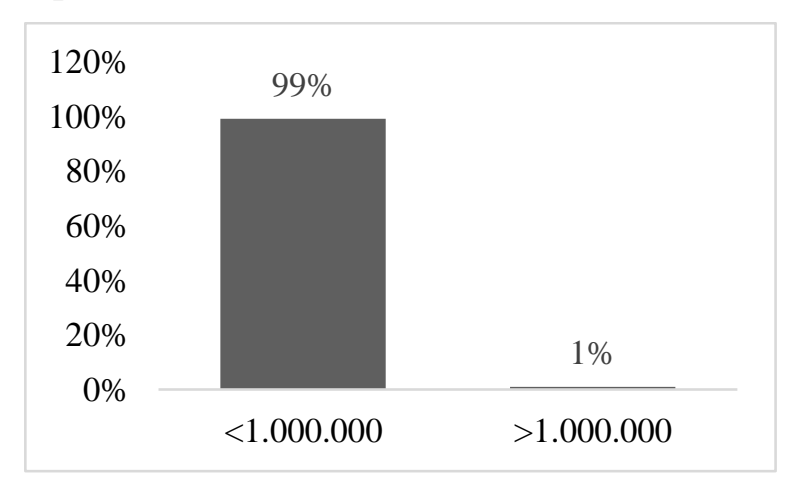

Gambar 2. Persentase pendapatan keluarga

Berdasarkan Tabel 3. Konsumsi pangan balita seperti makanan pokok $(53,7 \%)$, protein hewani $(57,3 \%)$, sayuran dan buah $(61,0 \%)$, serta Jajanan $(56,1 \%)$ sebagian besar berada pada kategori kurang. Hanya konsumsi pangan berupa protein nabati berada pada kategori cukup. 
Tabel 3. Jenis konsumsi pangan dan kecukupan gizi balita

\begin{tabular}{lcc}
\hline \multirow{2}{*}{$\begin{array}{c}\text { Jenis konsumsi } \\
\text { pangan balita }\end{array}$} & \multicolumn{2}{c}{ Kecukupan Gizi } \\
\cline { 2 - 3 } & Cukup & Kurang \\
\hline Makanan pokok & $46,3 \%$ & $53,7 \%$ \\
Protein hewani & $42,7 \%$ & $57,3 \%$ \\
Protein nabati & $54,9 \%$ & $45,1 \%$ \\
Sayur dan buah & $39,0 \%$ & $61,0 \%$ \\
Jajanan & $43,9 \%$ & $56,1 \%$ \\
\hline
\end{tabular}

\section{Pembahasan}

Stunting atau pendek merupakan keadaan gagal tumbuh pada balita akibat dari kekurangan gizi kronis terutama dalam 1000 hari pertama kehidupan sehingga anak terlalu pendek untuk usianya. Dalam penelitian ini, ditemukan balita yang mengalami status gizi kurang dan gizi buruk. Apabila kondisi tersebut terjadi terus menerus maka beresiko untuk mengalami stunting. Status gizi balita sangat penting untuk diperhatikan karena secara luas memiliki dampak besar dan berkepanjangan pada status kesehatan anak, perkembangan fisik dan mental serta produktivitas anak saat dewasa (Okoroigwe \& Okeke 2009).

Pada penelitian ini ditemukan pendidikan ibu sebagian besar adalah tamat SMA. Rendahnya pendidikan berpengaruh pada pengetahuan tentang pengolahan pangan lokal yang bergizi dan bermanfaat bagi kesehatan balita. Penelitian yang dilakukan oleh Farah Okky Aridiyah dan Ninna Rohmawati (2015) menemukan bahwa tingkat pendidikan ibu berperan penting terhadap kejadian stunting pada anak balita, baik di pedesaan maupun di perkotaan. Penelitian yang dilakukan oleh Anindita (2012) juga menemukan pada ibu yang berpendidikan rendah memiliki kecenderungan balita dengan status stunting lebih banyak terjadi. Tingkat pendidikan tinggi ibu kemungkinan dapat menjadi faktor penyebab terjadinya stunting pada anak. Ibu dengan pendidikan tinggi akan lebih banyak pengetahuannya dibandingkan dengan ibu yang berpendidikan rendah. Sehingga ibu yang berpendidikan tinggi dapat mengurangi kejadian stunting.

Hasil penelitian menunjukkan, hampir seluruh keluarga balita memiliki pendapatan di bawah UMR. Rendahnya tingkat pendapatan dibawah UMR dapat mempengaruhi pemilihan menu makanan. Sehingga menu makanan sangat terbatas, mereka tidak memperhatikan dari tingkat gizi maupun kecukupan gizi, melainkan hanya pada apakah konsumsi pangan dapat terpenuhi atau tidak.

Penelitian Handini (2013) menemukan adanya hubungan pendapatan keluarga dengan status gizi balita. Berbeda dengan pendapat Nursalam (2005) yang mengatakan pertumbuhan bayi tidak terlalu berpengaruh dengan pendapatan keluarga. Apabila keluarga dengan pendapatan rendah mampu mengelola makanan yang bergizi dengan bahan makanan 
yang sederhana dan murah maka pertumbuhan bayi juga akan menjadi baik.

Dalam penelitian ini konsumsi pangan balita seperti makanan pokok, protein hewani, sayuran dan buah, serta jajanan. sebagian besar berada pada kategori kurang. Hanya konsumsi pangan berupa protein nabati berada pada kategori cukup.

Menurut Solihin et al., (2013) salah satu faktor yang mempengaruhi status gizi balita, khususnya tinggi badan adalah kecukupan protein. Setiap penambahan satu persen tingkat kecukupan protein balita akan menambah zscore TB/U balita sebesar 0,024 satuan.

Begitupula dengan penelitian yang dilakukan oleh Purwaningrum dan Wardani (2013) yang menunjukkan asupan makanan (energi dan protein) berhubungan dengan status gizi balita. Balita yang status gizinya normal, sebagian besar mempunyai asupan makanan yang cukup. Hal ini menandakan bahwa makanan berpengaruh secara langsung terhadap status gizi (Damanik et al, 2010). Status gizi balita sangat ditentukan oleh konsumsi zat gizi (energi, protein, karbohidrat, dan lemak) yang berasal dari makanan seharihari. Bila tidak terjadi keseimbangan antara asupan zat gizi dengan kebutuhan maka akan terjadi masalah gizi.

\section{Kesimpulan}

Karakteristik balita sebagian besar berusia kurang dari 3 tahun atau usia batita. Pendidikan terakhir ibu hampir separuhnya adalah tamatan SMA. Sedangkan pendapatan keluarga hampir seluruhnya berpendapatan kurang dari Rp. 1.000.000. konsumsi pangan balita seperti makanan pokok, protein hewani, sayuran dan buah, serta jajanan. sebagian besar berada pada kategori kurang. Hanya konsumsi pangan berupa protein nabati berada pada kategori cukup.

\section{Ucapan terima kasih}

Penulis mengucapkan terimakasih kepada para pihak yang telah memberi dukungan dan kontribusi terhadap penelitian ini.

\section{Referensi}

Anindita, P. (2012). Hubungan Tingkat Pendidikan Ibu, Pendapatan Keluarga, Kecukupan Protein \& Zinc dengan Stunting (Pendek) pada Balita Usia 635

Bulan di Kecamatan Tembalang Kota Semarang. Jurnal Kesehatan Masyarakat Universitas Diponegoro, 1(2), 18764.

Devi, M. (2010). Analisis Faktor-Faktor yang Berpengaruh Terhadap Status Gizi Balita Di Pedesaan. Teknologi dan Kejuruan, Vol. 33(2): 183-192. 
Farah Okky, Aridiyah, Ninna Rohmawati (2015). Faktor-Faktor yang dapat Mempengaruhi Kejadian Stunting pada Anak Balita di Wilayah Pedesaan dan Perkotaan. E- Journal Pustaka Kesehatan Vol 3(1).

Gunawan, G., Fadlyana, E., Rusmil, K. (2011). Hubungan Status Gizi dan Perkembangan Anak Usia 1-2 Tahun. Sari Pediatri, Vol. 13(2): 142-146.

Handini, D. 2013. Hubungan Tingkat Pendapatan Keluarga dengan Status Gizi Balita di Wilayah Kerja Puskesmas Kalijambe (Doctoral dissertation,Universitas Muhammadiyah Surakarta).

Hariyadi, D., Ekayanti, I. (2011). Analisis Pengaruh Perilaku Keluarga Sadar Gizi Terhadap Stunting Di Provinsi Kalimantan Barat. Teknologi dan Kejuruan, Vol.34 (1): 71-80.

Jayati, L.D., Madanijah, S., Khomsan, A. (2014). Pola Konsumsi Pangan, Kebiasaan Makan, dan Densitas Gizi pada Masyarakat Kasepuhan Ciptagelar Jawa Barat. Penel Gizi Makan, Vol. 37(1): 33-42.

Khomsan, A., Anwar, F., Sukandar, D., Riyadi, H., Mudjajanto, E.S. (2006). Studi Tentang Pengetahuan Gizi Ibu dan Kebiasaan Makan pada Rumah Tangga di Daerah Dataran Tinggi dan Pantai.
Jurnal Gizi dan Pangan, Vol. 1(1): 2328.

Mitayani, S. W. (2010). Buku Saku Ilmu Gizi. Jakarta: Cv. Trans Info Media.

Nadiyah, Briawan, D., Martianto, D., (2014). Faktor Risiko Stunting pada Anak Usia 0-23 Bulan Di Provinsi Bali, Jawa Barat, dan Nusa Tenggara Timur. Jurnal Gizi dan Pangan, Vol. 9(2): 125-132.

Nursalam. (2005). Asuhan Keperawatan Bayi dan Anak. Jakarta : Salemba Medika.

Okoroigwe F, Okeke E. (2009). Nutritional status of preschool children aged 2-5 years in Aguata L. G. A of Anambra State, Nigeria. Int J Nutr Metabol 1(1).

Pahlevi, A.E. (2012). Determinan Status Gizi pada Siswa Sekolah Dasar. Jurnal Kesehatan Masyarakat, Vol. 7(2): 122126.

Picauly, I., Toy, S.M. (2013). Analisis Determinan dan Pengaruh Stunting Terhadap Prestasi Belajar Anak Sekolah di Kupang dan Sumba Timur, NTT. Jurnal Gizi dan Pangan, Vol. 8(1): 5562.

Purwaningrum, S., \& Wardani, Y. (2013). Hubungan antara Asupan Makanan dan Status Kesadaran Gizi Keluarga dengan Status Gizi Balita di Wilayah Kerja Puskesmas Sewon I, Bantul. Jurnal Kesehatan Masyarakat (Journal of Public Health), 6(3). 
Indrastuti dkk. Karakteristik Keluarga Dan Pola Konsumsi Pangan Balita Di Wilayah Locus Stunting Kecamatan Balanipa Kabupaten Polewali Mandar. Journal of Borneo Holistic Health, Vol.3, No. 2

Putri, R.F., Sulastri, D., Lestari, Y. (2015).

Faktor-Faktor yang Berhubungan dengan Status Gizi Anak Balita Di Wilayah Kerja Puskesmas Nanggalo Padang. Jurnal Kesehatan Andalas, Vol. 4(1):254-261.
Solihin RDM, Anwar F, Sukandar D. (2013). Kaitan antara status gizi, perkembangan kognitif, dan perkembangan motorik pada anak usia prasekolah. Penel Gizi Makan, Vol. 36(1):62-72. 